\title{
SISTEM PENDUKUNG KEPUTUSAN PEMILIHAN SISWA BERPRESTASI DI JEMAAT MORIA SAMARINDA SEBERANG DENGAN METODE SIMPLE ADDITIVE WEIGTHTING
}

\author{
Anton Topadang ${ }^{1}$, Tien Rahayu Tulili \\ ${ }^{1,2)}$ Prodi Teknik Informatika Multimedia, Politeknik Negeri Samarinda \\ Email : antontpd@gmail.com ${ }^{I}$, tien,tulili@polnes.ac.id ${ }^{2}$
}

\begin{abstract}
Abstrak - Sistem pendukung keputusan pemilihan siswa berprestasi ini dibangun melalui beberapa tahapan yaitu pengumpulan data, dan informasi dilanjutkan dengan analisis dokumen. Tahapan kedua adalah pengolahan data dan informasi untuk mendapatkan rancangan sistem yang akan dibangun. Tahapan ketiga adalah analisis sistem yang meliputi input data siswa, pembobotan kriteria, sampai pada perankingan alternatif. Metode yang digunakan pada penelitian ini adalah Metode Simple Additive Weighting yang memiliki konsep dasar untuk mencari penjumlahan terbobot dari rating kinerja pada setiap alternatif pada semua atribut. Penelitian ini menghasilkan output berupa nama, nilai akhir dan ranking setiap alternative yang selanjutnya dapat dijadikan acuan bagi majelis gereja Toraja Jemaat Moria Samarinda Seberang dalam menentukan siswa-siswi sma/smk yang berhak mendapat beasiswa berprestasi pada setiap tahunnya.
\end{abstract}

Kata kunci: beasiswa, seleksi, simple additive weighting

\section{PENDAHULUAN}

Dalam rangka pelayanan dan kepedulian kepada warga Jemaat, Majelis Gereja Toraja Jemaat Moria Samarinda Seberang melalui program kerja jemaat mengadakan bantuan bagi pelajar berupa beasiswa berprestasi kepada siswa-siswi anak warga Jemaat Moria Samarinda Seberang pada tingkat SMU/SMK. Program bantuan beasiswa bagi anakanak warga jemaat yang berprestasi telah diberikan pada beberapa tahun terakhir. Dalam menentukan penerima beasiswa berprestasi tersebut, telah menggunakan bantuan komputer tetapi penggunaanya belum optimal. Hal ini menyebabkan pengelolaan data beasiswa yang tidak efisien terutama dari segi waktu dan banyaknya perulangan proses yang sebenarnya dapat diefisienkan, oleh karena itu, perlu adanya sistem pendukung keputusan untuk mempermudah perhitungan semua kriteria yang mendukung untuk penentuan beasiswa, sehingga dapat mempersingkat waktu penyelesaian dan dapat meningkatkan kualitas keputusan dalam penentuan penerima beasiswa berprestasi.

Pada penelitian sebelumnya yang dilakukan oleh Sri Eniyanti (2011) dengan judul Perancangan Sistem Pendukung Pengambilan Keputusan untuk Penerimaan Beasiswa dengan Metode SAW (Simple Additive Weigthting) dalam penelitiannya mengatakan bahwa metode ini digunakan untuk melakukan penilaian atau seleksi terhadap beberapa alternatif dalam jumlah terbatas. Dalam hal ini alterantif yang dimaksud adalah berhak menerima beasiswa berdasarkan kriteria-kriteria yang sudah ditentukan. Dengan metode ini penilaian akan lebih tepat karena didasarkan pada nilai kriteria dan bobot yang sudah ditentukan sehingga mendapatkan hasil yang lebih akurat terhadap siapa yang akan menerima beasiswa tersebut.

Pada penelitian ini akan dibangun sistem pendukung keputusan siswa berprestasi. Sistem ini bertujuan untuk memperoleh hasil perankingan siswa berprestasi secara cepat dan objektif. Hasil perankingan ini akan membantu pihak Majelis Gereja Toraja Jemaat Moria Samarinda Seberang dalam memilih siswa-siswi berprestasi yang berhak memperoleh beasiswa pada setiap tahunnya.

\section{TINJAUAN PUSTAKA \\ 2.1 Pengertian Beasiswa}

Pengertian beasiswa adalah pemberian berupa bantuan keuangan yang diberikan kepada perorangan yang bertujuan untuk digunakan demi kelangsungan pendidikan yang ditempuh. Beasiswa dapat diberikan oleh lembaga pemerintah, perusahaan, ataupun yayasan. Pemberian beasiswa dapat dikategorikan pada pemberian cuma-cuma ataupun pemberian dengan ikatan kerja (biasa disebut ikatan dinas) setelah selesainya pendidikan. Lama ikatan dinas ini berbeda-beda, tergantung pada lembaga yang memberikan beasiswa tersebut.

Pada dasarnya, beasiswa adalah penghasilan bagi yang menerimanya. Beasiswa ini sesuai dengan ketentuan pasal 4 ayat (1) UU PPh/2000.

Disebutkan pengertian penghasilan adalah tambahan kemampuan ekonomis dengan nama dan dalam bentuk apapun yang diterima atau diperoleh dari sumber Indonesia atau luar Indonesia yang dapat digunakan untuk konsumsi atau menambah kekayaan Wajib Pajak (WP), karena beasiswa bisa diartikan menambah kemampuan ekonomis bagi penerimanya, berarti beasiswa merupakan penghasilan (Jawa Pos, 2009).

\subsection{Data Mining}

Data mining adalah suatu istilah yang digunakan untuk menguraikan penemuan pengetahuan di dalam database. Data mining adalah proses yang menggunakan teknik statistik, matematika, kecerdasan buatan dan machine learning untuk mengekstraksi dan mengidentifikasi 
informasi yang bermanfaat dan pengetahuan yang terakit dari berbagai database besar(Prasetyo, Eko, 2012). Data mining adalah teknik statistik dan matematika yang digunakan untuk menemukan hubungan yang berarti, pola dan kecenderungan dengan memeriksa dalam sekumpulan data yang tersimpan(Pressman, Roger S. 2012).

Pada data mining terdapat beberapa tahap proses yang ada, antara lain :

1. Mendefinisikan masalah, menentukan input dan output untuk form, menentukan nilai efisiensi, menentukan keakuratan dan sebagainya.

2. Mengumpulkan dan memilih data yang akan digunakan.

3. Mempersiapkan data, seperti mengubah bentuk data ke bentuk yang sesuai, pembersihan data, atau menggabungkan data dari sumber yang berbeda.

4. Menentukan metode yang sesuai terdiri dari dua bagian:

a. Memilih model atau algoritma, seprti menggunakan model yang seperti apa, memilih untukmenggunakan algoritma apa

b. Memilih parameter model, misalnya jumlah node pada tiap tingkat jika artificial network digunakan.

5. Pelatihan atau testing, melakukan tes pada data dengan menerapkannya menggunakan algoritma.

6. Interpretasi, evaluasi dan visualisasi pola: adanya sesuatu yang baru dan menarik, lakukaniterasi jika diperlukan. Data mining dibagi menjadi beberapa kelompok berdasarkan tugas yang dapat dilakukan yaitu:

a. Klasifikasi

b. Klasifikasi merupakan tugas data mining yang paling umum. Ciri dari klasifikasi adalah memiliki definisi yang jelas tentang kelas-kelas (predifined classes) dan training set. Klasifikasi bertujuan memprediksi kelas dari suatu data yang belum diketahui kelasnya. Dalam mencapai tujuan tersebut, proses klasifikasi membentuk suatu model yang mampu membedakan data kedalam kelas-kelas yang berbeda berdasarkan aturan atau fungsi tertentu.

c. Deskripsi

d. Deskripsi adalah cara untuk menggambarkan pola dan kecenderungan yang terdapat alamdata.

e. Estimasi

f. Estimasi hampir sama dengan klasifikasi, kecuali variabel target estimasi lebih ke arah numerik daripada ke arah kategori. Model dibangun menggunakan record lengkap yang menyediakan nilai dari variabel target sebagai nilai prediksi. Selanjutnya, pada peninjauan berikutnya estimasi nilai dari variabel target dibuat berdasarkan nilai variabel prediksi.

g. Pengelompokan (clustering) h. Pengelompokan adalah tugas data mining yang menggunakan metode populasi yang heterogen menjadi sejumlah kelompok data yang homogen. Data dikelompokan berdasarkan ciri-ciri yang sama tidak tergantung pada predefined classes dan training set.

i. Prediksi

j. Prediksi hampir sama dengan klasifikasi dan estimasi, kecuali bahwa dalam prediksi nilai dari hasil akan ada di masa mendatang. Beberapa metode dan teknik yang digunakan dalam klasifikasi dan estimasi dapat pula digunakan (untuk keadaan yang tepat) untuk prediksi.

\section{3 Simple Additive Weighting}

Metode Simple Additive Weighting (SAW) sering juga dikenal istilah metode penjumlahan terbobot. Konsep dasar metode SAW adalah mencari penjumlahan terbobot dari rating kinerja pada setiap alternatif pada semua atribut (Fishburn,1967). Konsep dasar metode SAW adalah mencari penjumlahan terbobot dari rating kinerja pada setiap alternatif pada semua kriteria(Kusumadewi, 2006). Metode SAW mengenal adanya 2 (dua) atribut yaitu kriteria keuntungan (benefit) dan kriteria biaya (cost). Perbedaan mendasar dari kedua kriteria ini adalah dalam pemilihan kriteria ketika mengambil keputusan. Adapun langkah penyelesaian dalam menggunakannya adalah:

a. Menentukan alternatif, yaitu Ai.

b. Menentukan kriteria yang akan dijadikan acuan dalam pengambilan keputusan, yaitu $\mathrm{Cj}$.

c. Memberikan nilai rating kecocokan setiap alternatif pada setiap kriteria.

d. Menentukan bobot preferensi atau tingkat kepentingan (W) setiap kriteria. b

e. $\mathrm{W}=[\mathrm{W} 1 \mathrm{~W} 2 \mathrm{~W} 3 \mathrm{~W} 4 \ldots \mathrm{Wj}]$

f. Membuat tabel rating kecocokan dari setiap alternatif pada setiap kriteria.

g. Membuat matrik keputusan X yang dibentuk dari tabel rating kecocokan dari setiap alternatif padasetiap kriteria. Nilai X setiap alternatif (Ai) pada setiap kriteria $(\mathrm{Cj})$ yang sudah ditentukan, dimana, $i=1,2, \ldots m$ dan $j=1,2, \ldots n$.

h. Melakukan normalisasi matrik keputusan $\mathrm{X}$ dengan cara menghitung nilai rating kinerja ternomalisasi (rij) dari alternatif $\mathrm{Ai}$ pada kriteria $\mathrm{Cj}$.

Keterangan :

1. Dikatakan kriteria keuntungan apabila nilai Xij memberikan keuntungan bagi pengambil keputusan, sebaliknya kriteria biaya apabila Xij menimbulkan biaya bagi pengambil keputusan.

2. Apabila berupa kriteria keuntungan maka nilai Xij dibagi dengan nilai Maxi(Xij) dari setiap kolom, sedangkan untuk kriteria 
biaya, nilai Mini(Xij) dari setiap kolom dibagi dengan nilai Xij.

i. Hasil dari nilai rating kinerja ternomalisasi (rij) membentuk matrik ternormalisasi (R)

j. Hasil akhir nilai preferensi (Vi) diperoleh dari penjumlahan dari perkalian elemen baris matrik ternormalisasi (R) dengan bobot preferensi (W) yang bersesuaian eleman kolom matrik (W). Hasil perhitungan nilai Vi yang lebih besar mengindikasikan bahwa alternatif $\mathrm{Ai}$ merupakan alternatif terbaik.

Metode SAW membutuhkan proses normalisasi matriks keputusan (X) ke suatu skala yang dapat diperbandingkan dengan semua rating alternative yang ada(Kusumadewi, 2006).

Berikut rumus SAW:

$r_{i j}=\left\{\begin{array}{l}\frac{x_{i j}}{\max _{i} x_{i j}} j i k a j \text { adalah atribut keuntungan } \\ \frac{\min _{i} x_{i j}}{x_{i j}} j i k a j \text { adalah atribut biaya (cost) }\end{array}\right.$

\section{Keterangan :}

rij = nilai rating kinerja ternormalisasi

$\mathrm{xij}=$ nilai atribut yang dimiliki dari setiap criteria

Max xij = nilai terbesar dari setiap criteria

Min xij = nilai terkecil dari setiap criteria

benefit $=$ jika nilai terbesar adalah terbaik

cost $=$ jika nilai terkecil adalah terbaik dimana rij adalah rating kinerja ternormalisasi dari alternative ai pada atribut $\mathrm{Cj} ; \mathrm{i}=1,2, \ldots, \mathrm{m}$ dan $\mathrm{j}=1,2, \ldots, \mathrm{n}$. Nilai presensi untuk setiap alternative(Vi) diberikan sebagai:

$$
V_{i} \sum_{j=1}^{n} V_{j} r_{i j}
$$

Keterangan :

$\mathrm{Vi}=$ rangking untuk setiap alternative

$\mathrm{Wj}=$ nilai bobot dari setiap criteria

rij = nilai rating kinerja ternormalisasi

\section{METODE PENELITIAN}

\subsection{Metode Simple Additive Weighting (SAW)}

Metode SAW merupakan metode yang dikenal dengan metode penjumlahan terbobot dimana dibutuhkan proses normalisasi matriks keputusan ke suatu skala yang dapat diperbandingkan dengan semua alternatife yang ada. Dalam penerapan algoritma Simple Additive Wieghting terhadap 5 calon siswa terdapat beberapa langkah yang harus dilakukan, antara lain:

1. Menentukan kriteria yang digunakan dalam

pengolahan data.

a. Kriteria Benefit

1. Nilai Rata-rata Raport (disimbolkan C1)

2. Nilai Lomba (disimbolkan C2)

3. Semester (disimbolkan C3)

b. Kriteria Cost

Tidak ada kriteria cost pada atribut tersebut.
2. Pengisian nilai bobot pada masing-masing atribut/kriteria seperti pada table 1 .

Tabel 1. Bobot Kriteria

\begin{tabular}{cl|c}
\hline Kriteria & Keterangan & Bobot \\
\hline C1 & $\begin{array}{l}\text { Nilai Rata-rata } \\
\text { Raport }\end{array}$ & 5 \\
\hline C2 & Nilai Lomba & 3 \\
\hline C3 & Semester & 2 \\
\hline
\end{tabular}

Ada tiga kriteria dalam pemilihan siswa-siswi berprestasi pada Gereja Toraja Jemaat Moria Samarinda Seberang yaitu Nilai rata-rata raport, nilai lomba, dan semester yang harus ditentukan nilai bobotnya. Adapun kriteria dan bobot untuk masing-masing kriteria adalah:

a. Kriteria Nilai Raport

Tabel 2. Nilai Rata-rata Raport

\begin{tabular}{l|l|c}
\hline $\begin{array}{l}\text { Nilai rata-rata } \\
\text { Raport }\end{array}$ & \multicolumn{1}{l}{$\begin{array}{l}\text { Bilangan } \\
\text { fuzzy }\end{array}$} & Nilai \\
\hline $\mathrm{C} 1<60$ & Rendah(R) & 0,25 \\
\hline $\mathrm{C} 1>60-\mathrm{C} 1<$ & Sedang(S) & 0,50 \\
70 & & \\
\hline $\mathrm{C} 1>70-\mathrm{C} 1<$ & Tinggi(T) & 0,75 \\
80 & & \\
\hline $\mathrm{C} 1>80-\mathrm{C} 1=$ & $\begin{array}{l}\text { Sangat } \\
100\end{array}$ & 1 \\
\hline
\end{tabular}

b. Nilai Lomba

Tabel 3. Bobot Lomba

\begin{tabular}{l|l|c}
\hline Nilai Lomba & Bilangan fuzzy & Nilai \\
\hline Tanpa Prestasi & Sangat rendah & 0 \\
\hline Tkt. Kecamatan & Rendah(R) & 0,25 \\
\hline $\begin{array}{l}\text { Tkt. } \\
\text { Kabupaten/kota }\end{array}$ & Sedang(S) & 0,50 \\
\hline Tkt. Propinsi & Tinggi(T) & 0,75 \\
\hline Tkt. Nasional & $\begin{array}{l}\text { Sangat } \\
\text { Tinggi(ST) }\end{array}$ & 1 \\
\hline
\end{tabular}

c. Nilai Semester

Tabel 4. Bobot Semester

\begin{tabular}{c|c|c}
\hline Semester(C3) & \multicolumn{1}{l}{$\begin{array}{l}\text { Bilangan } \\
\text { Fuzzy }\end{array}$} & Nilai \\
\hline Smtr 2 & Sedang & 0,50 \\
\hline Smtr 4 & Tinggi & 0,75 \\
\hline Smtr 6 & Sangat Tinggi & 1 \\
\hline
\end{tabular}

\subsection{Perhitungan SAW Untuk Pemilihan Siswa Berprestasi}

Pada uji sistem aplikasi ini diambil sepuluh sampel calon siswa berprestasi dengan data sebagai berikut : 


\section{a. Data Calon Siswa}

Tabel 5. Data Calon Siswa

\begin{tabular}{|c|c|c|c|c|}
\hline No & Nama & $\begin{array}{l}\text { Rata- } \\
\text { rata } \\
\text { Raport }\end{array}$ & $\begin{array}{l}\text { Prestasi } \\
\text { Lomba }\end{array}$ & Semester \\
\hline 1 & Matius & 88.25 & $\begin{array}{c}\text { Juara II } \\
\text { Tk. } \\
\text { Kecamatan }\end{array}$ & 4 \\
\hline 2 & Hana & 89.76 & & 2 \\
\hline 3 & Markus & 87.88 & $\begin{array}{l}\text { Juara I Tk. } \\
\text { Kabupaten. }\end{array}$ & 6 \\
\hline 4 & Piter & 90.65 & $\begin{array}{l}\text { Juara I Tk. } \\
\text { Kecamatan }\end{array}$ & 6 \\
\hline 5 & Elisabeth & 79.90 & & 4 \\
\hline 6 & Yohanes & 97.84 & $\begin{array}{c}\text { Juara I Tk. } \\
\text { Provinsi. }\end{array}$ & 4 \\
\hline 7 & Stefanus & 78.90 & & 2 \\
\hline 8 & Daniel & 87.57 & $\begin{array}{c}\text { Juara I Tk. } \\
\text { Nasional } \\
\end{array}$ & 6 \\
\hline 9 & Lukas & 89.87 & & 4 \\
\hline 10 & Agustina & 94.79 & & 2 \\
\hline
\end{tabular}

Berdasarkan pada table 5 di atas, maka selanjutnya dapat dianalisa dan ditetapkan nilai bobot terhadap kriteria-kriteria yang akan digunakan sebagai parameter penentuan siswa-siswi berprestasi yang layak menerima beasiswa berprestasi.

Tabel 6. Rating Kecocokan Alternatif

\begin{tabular}{c|c|c|c}
\hline \multirow{2}{*}{ Alternatif } & \multicolumn{3}{|c}{ Kriteria } \\
\cline { 2 - 4 } & C1 & C2 & C3 \\
\hline A1 & 1.00 & 0.25 & 0.75 \\
\hline A2 & 1.00 & 0.00 & 0.50 \\
\hline A3 & 1.00 & 0.50 & 1.00 \\
\hline A4 & 1.00 & 0.25 & 1.00 \\
\hline A5 & 0.75 & 0.00 & 0.75 \\
\hline A6 & 1.00 & 0.75 & 0.75 \\
\hline A7 & 0.75 & 0.00 & 0.50 \\
\hline A8 & 1.00 & 1.00 & 1.00 \\
\hline A9 & 1.00 & 0.00 & 0.75 \\
\hline A10 & 1.00 & 0.00 & 0.50 \\
\hline \multicolumn{3}{|c}{}
\end{tabular}

Selanjutnya dapat diubah dalam bentuk matrik keputusan X.

\section{c. Matrik Keputusan X}

$$
\mathrm{X}=\left(\begin{array}{ccc}
1.00 & 0.25 & 0.75 \\
1.00 & 0.00 & 0.50 \\
1.00 & 0.50 & 1.00 \\
1.00 & 0.25 & 1.00 \\
0.75 & 0.00 & 0.75 \\
1.00 & 0.75 & 0.75 \\
0.75 & 0.00 & 0.50 \\
1.00 & 1.00 & 1.00 \\
1.00 & 0.00 & 0.75 \\
1.00 & 0.00 & 0.50
\end{array}\right)
$$

Setelah dijadikan matriks kemudian nilai matriks di atas dinormalisasikan dengan rumus :

$$
r_{i j}=\left\{\begin{array}{l}
\frac{x_{i j}}{\max _{i} x_{i j}} j i k a j \text { adalah atribut keuntungan } \\
\frac{\min _{i} x_{i j}}{x_{i j}} j i k a j \text { adalah atribut biaya (cost) }
\end{array}\right.
$$

Keterangan :

rij = nilai rating kinerja ternormalisasi .

kriteria.

xij = nilai atribut yang dimiliki dari setiap

Maxi xij = nilai terbesar dari setiap kriteria.

Mini xij = nilai terkecil dari setia kriteria

Benefit $=$ jika nilai terbesar adalah terbaik

Cost $=$ jika nilai terkecil adalah terbaik .

Pada kasus ini semuanya menggunakan atribut keuntungan (benefit) yaitu nilai ujian nasional, prestasi, anak pegawai/bina lingkungan, dan domisili.

\section{d. Matrik Normalisasi}

Hasil dari nilai rating kinerja ternormalisasi akan membentuk matrik ternormalisasi sebagi berikut :

$$
\mathbf{R}=\left(\begin{array}{lll}
1.00 & 0.25 & 0.75 \\
1.00 & 0.00 & 0.50 \\
1.00 & 0.50 & 1.00 \\
1.00 & 0.25 & 1.00 \\
0.75 & 0.00 & 0.75 \\
1.00 & 0.75 & 0.75 \\
0.75 & 0.00 & 0.50 \\
1.00 & 1.00 & 1.00 \\
1.00 & 0.00 & 0.75 \\
1.00 & 0.00 & 0.75
\end{array}\right)
$$

\section{e. Nilai preferensi}

Nilai preferensi diperoleh dari setiap alternative(Vi) dijumlahkan dengan hasil kali antara matriks ternormalisasi( $\mathrm{R})$ dengan nilai bobot(W). Nilai preferensi dari setiap alternative calon siswa adalah sebagai berikut :

$$
\begin{aligned}
& \text { V1 }=(0.5 * 1)+(0.3 * 0.25)+(0.2 * 0.75)=0.28 \\
& \text { V2 }=(0.5 * 1)+(0.3 * 0)+(0.2 * 0.50)=0.10 \\
& \text { V3 }=(0.5 * 1)+(0.3 * 0.5)+(0.2 * 1)=0.60 \\
& \text { V4 }=(0.5 * 1)+(0.3 * 0.25)+(0.2 * 1)=0.40 \\
& \text { V5 }=(0.5 * 0.75)+(0.3 * 0)+(0.2 * 0.75)=0.40 \\
& \text { V6 }=(0.5 * 1)+(0.3 * 0.75)+(0.2 * 0.75)=0.60 \\
& \text { V7 }=(0.5 * 0.75)+(0.3 * 0)+(0.2 * 0.50)=0.28 \\
& \text { V8 }=(0.5 * 1)+(0.3 * 1)+(0.2 * 1)=1.00 \\
& \text { V9 }=(0.5 * 1)+(0.3 * 0)+(0.2 * 0.75)=0.50 \\
& \text { V10 }=(0.5 * 1)+(0.3 * 0)+(0.2 * 0.50)=0.30
\end{aligned}
$$

Berdasarkan pada nilai preferensi di atas, maka dapat diurutkan nilai tertinggi sampai terendah untuk dapat direkomendasi dalam menentukan penerima beasiswa berprestasi pada Gereja Toraja Jemaat Moria Samarinda Seberang pada setiap tahunnya. 
Tabel 7. Ranking Hasil Penilaian SAW

\begin{tabular}{c|l|c|c}
\hline \multirow{2}{*}{ Kode } & \multicolumn{1}{c}{$\begin{array}{c}\text { Nama } \\
\text { Siswa }\end{array}$} & $\begin{array}{c}\text { Nilai } \\
\text { Akhir }\end{array}$ & Ranking \\
\hline A1 & Matius & 0.28 & 8 \\
\hline A2 & Hana & 0.10 & 10 \\
\hline A3 & Markus & 0.60 & 2 \\
\hline A4 & Piter & 0.40 & 5 \\
\hline A5 & Elisabeth & 0.40 & 6 \\
\hline A6 & Yohanes & 0.60 & 3 \\
\hline A7 & Stefanus & 0.28 & 9 \\
\hline A8 & Daniel & 1.00 & 1 \\
\hline A9 & Lukas & 0.50 & 4 \\
\hline A10 & Agustina & 0.30 & 7 \\
\hline
\end{tabular}

\section{KESIMPULAN}

Dari hasil penelitian dan pembahasan, maka dapat diambil kesimpulan bahwa sistem ini menghasilkan output berupa nama, nilai akhir dan ranking setiap alternative yang selanjutnya dapat dijadikan acuan bagi Majelis Gereja Toraja Jemaat Moria Samarinda Seberang dalam memilih siswasiswa sma/smk berprestasi pada setiap tahunnya.

\section{REFEFRENSI}

[1] Sri Eniyanti (2011). Perancangan Sistem Pendukung Pengambilan Keputusan untuk Penerimaan Beasiswa dengan Metode SAW (Simple Additive Weigthting), Dinamik-Jurnal Teknologi Informasi 16 (2).

[2] S. Kusumadewi, S. Hartati, A. Harjoko, dan R. Wardoyo, Fuzzy Multiple Attribut Decision Making (FUZZY MADM), Yogyakarta, Graha Ilmu, 2006.

[3] Agassi V, Yoga Aditya; Dharma W, Indra; Romlah, Romlah. Sistem Pendukung Keputusan Penerimaan Beasiswa Dengan Metode Simple Additive Weighting (Saw) Di Politeknik Negeri Malang. Jurnal Informatika Polinema.

[4] Hanifah, I. N. (2014). Sistem Pendukung Keputusan Pemilihan Guru Berprestasi dengan Simple Additive Weighting. Jurnal Teknik Elektro Universitas Negeri Semarang, 6(1), 45-50.

[5] Lemantara, J., Setiawan, N. A., \& Aji, M. N. (2013). Rancang Bangun Sistem Pendukung Keputusan Pemilihan Mahasiswa Berprestasi Menggunakan Metode AHP dan Promethee. JNTETI, 2(4), 20-28. 